\title{
Concentração do lactato-L no líquido cefalorraquidiano de bovinos sadios e com doenças neurológicas
}

Juliana Massitel Curti', Gustavo Rodrigues Queiroz, Priscilla Fajardo Valente Pereira, Paola Denis Palácios, Maíra Moreira dos

Santos, José Guilherme do Rego Marcondes, Efa Depe, Karina Keller Marques da Costa Flaiban, Júlio Augusto Naylor Lisbôa

Programa de Pós-Graduação em Ciência Animal, Centro de Ciências Agrárias (CCA), Universidade Estadual de Londrina (UEL), Londrina, PR, Brasil

*Autor correspondente

e-mail: ju_massitel@hotmail.com

\section{Resumo}

O aumento da concentração de lactato no líquido cefalorraquidiano (LCR) tem sido observado nos casos de traumas com danos encefálicos, de doenças inflamatórias virais, de doenças bacterianas, de neoplasias e de convulsões em humanos. 0 objetivo do presente trabalho foi avaliar a concentração do lactato- $\mathrm{L}$ no LCR de bovinos acometidos por diferentes doenças neurológicas e de comparar os resultados com os observados em bovinos saudáveis. Foram avaliadas 41 amostras de bovinos com doenças neurológicas, sendo elas raiva $(n=15)$, encefalite herpética $(n=16)$ e encefalite bacteriana $(n=10)$, e 10 amostras de bovinos saudáveis. As amostras de LCR dos bovinos sadios e doentes foram colhidas com sedação prévia e punção no espaço atlanto-ociptal e posteriormente foi colhido o plasma. As amostras dos bovinos doentes são provenientes de projeto de pesquisa intitulado "Doenças neurológicas dos bovinos no estado do Paraná - Diagnóstico diferencial e epidemiologia”, e foram mantidas por congelação (- 20ํㅡ) até a mensuração do lactato-L. O lactato-L foi mensurado pelo método colorimétrico no LCR e no plasma. A análise de variância foi empregada para comparação entre os grupos, admitindo-se a probabilidade de erro de 5\%. Os bovinos sadios apresentaram concentração de lactato-L no LCR de 2,86 \pm 0,28 mmol/L, no plasma de 1,03 \pm 0,51 mmol/L, e a sua relação LCR:plasma foi de 3,36 \pm 1,52. Quando comparado o lactato-L no LCR dos bovinos sadios com os doentes não há diferença estatística com a raiva $(4,85 \pm 1,51 \mathrm{mmol} / \mathrm{L})$ e a encefalite herpética $(4,87 \pm 3,27 \mathrm{mmol} / \mathrm{L})$, porém as encefalites bacterianas apresentam uma maior concentração $(7,22 \pm 4,58$ $\mathrm{mmol} / \mathrm{L}$ ), resultado que corrobora com os achados na medicina humana, em que o lactato-L é utilizado como biomarcador auxiliando no diagnóstico e diferenciação das meningoencefalites de origens viral e bacteriana. Pode-se afirmar que nos bovinos com encefalite bacteriana haverá aumento na concentração de 
lactato-L no LCR podendo ser utilizado como método de auxílio no diagnóstico ante-mortem, entretanto, nos casos de raiva e encefalite herpética esse fato não ocorre. 